\title{
Yield Performance and Economic Studies of Cabbage (Brassica oleracea var. capitata) as Influenced by Different Sources and Levels of Sulphur
}

\author{
R. Bhat ${ }^{1}$, Shahid B. Dar ${ }^{2 *}$ and R. Zahida ${ }^{2}$ \\ ${ }^{1}$ Division of Vegetable Sciences, SKUAST-Kashmir, FOA, Wadura-193201, J\&K, India \\ ${ }^{2}$ Division of Agronomy, SKUAST-Kashmir, FOA, Wadura-193201, J\&K, India \\ *Corresponding author
}

\section{A B S T R A C T}

A field experiment was conducted during Rabi 2012-13 and 2013-14 to study economics of cost of cultivation head yield and seed yield of cabbage as influenced by different

Keywords

Cabbage, Seed yield, Head yield, Sulphur and Economics.

Article Info

Accepted:

04 September 2017 Available Online:

10 October 2017 sources and levels of sulphur. The experiment was laid in a randomized block design with three replications. Three sources of sulphur i.e., gypsum, elemental sulphur and potassium sulphate with three levels i.e., 40, 70 and $100 \mathrm{~kg} \mathrm{~S} h a^{-1}$ for each source were tried in the experiment. Pooled data of two years showed potassium sulphate as a source of sulphur recorded maximum head yield plot ${ }^{-1}(30.8 \mathrm{~kg})$ and head yield ha ${ }^{-1}(408.4 \mathrm{q})$ and seed yield per plant $(12.9 \mathrm{~g})$, and seed yield per hectare $(4.8 \mathrm{q})$. Further, increasing levels of sulphur up to $70 \mathrm{~kg} \mathrm{ha}^{-1}$ showed significant results. Maximum cost of cultivation ( $₹ 230577.5 \mathrm{ha}^{-1}$ ) and $\left(₹ 242390.0 \mathrm{ha}^{-1}\right)$ was estimated in application of $100 \mathrm{~kg} \mathrm{~S} \mathrm{ha}^{-1}$ as Elemental sulphur and minimum ( $₹ 130577.5)$ and ( $₹$ 130577.5) under control for head yield and seed yield of cabbage, respectively. Optimum dose of sulphur registered net returns of ₹ 404251.3 $\mathrm{ha}^{-1}$ and of $₹ 271457.3 \mathrm{ha}^{-1}$ with B: C ratio of 3.4 and 2.5 for cabbage head and seed production respectively. Economic studies indicated that fertilizer source Potassium Sulphate @ $70 \mathrm{~kg} \mathrm{~S} \mathrm{ha}^{-1}$ gave maximum net returns of ₹ $485925.8 \mathrm{ha}^{-1}$ and $₹ 3210128.0$ $\mathrm{ha}^{-1}$ with $\mathrm{B}: \mathrm{C}$ ratio of 4.1 and 3.0 for cabbage head and seed production respectively.

\section{Introduction}

Cabbage (Brassica oleracea var. capitata) is the second most important cole crop after cauliflower, which was originated in Europe and in the Mediterranean region, evolved from a leafy mustard herb "Caboche" a French word believed to be the root of the English name of cabbage and is derived from the Normanno picard word which means "head". Cabbage falls under cole group and all cole crops have one common trait i.e., genetic potential to thicken various parts. The seeds of cabbage used to be imported from Europe and the attempts to produce seeds were undertaken during the Second World War when the supply was cut off. It is cultivated in most countries worldwide just like other common cruciferous vegetables like broccoli, brussels sprout and cauliflower which are part of our day to day cooking.

In India, it is grown over an area of 400 thousand hectares with a production of 9039 thousand metric tons, and, the productivity of the crop is quite low 22.6 metric tons/hectare. West Bengal is the largest grower of cabbage and produces 2197.4 thousand metric tons on 
an area of 78.2 thousand hectares which is about $27 \%$ of the total of the country. Orissa (14\%) and Bihar (9\%) occupies second and third position respectively. The other major growers of cabbage are Assam, Karnataka, Maharashtra, and Gujarat (Anonymous, 2011). In J\&K, cabbage is grown over an area of 2264 hectares with the production of 69726 $\mathrm{t}$ of which Kashmir occupies an area of 750 hectare with the production of 20950 tones (Anonymous, 2012a).

Cabbages are highly responsive to fertilizer application. Fertilizers offer the best means of increasing yield and maintaining soil health. In addition to $\mathrm{N}, \mathrm{P}$ and $\mathrm{K}$ nutrients, sulphur has been found to be very much beneficial (Hara and Sonoda, 1981).

Sulphur is increasingly being recognized as the fourth major plant nutrient after nitrogen, phosphorus and potassium (Jamal et al 2010). Sulphur is best known for its role in the synthesis of proteins, oils, vitamins and is associated with the production of superior nutritional and market quality.

Cabbage for seed production is a winter biennial crop and sulphur also provides winter hardiness and drought tolerance besides control of insects, pests and diseases. Optimum use of fertilizers containing sulphur improves utilization of nutrients, especially nitrogen. Keeping these aspects in view, the present investigation was undertaken.

\section{Materials and Methods}

Field experiments were carried out at Vegetable Experimental Farm, Division of Vegetable Science Rabi season of 2012-13 and 2013-14 located at $34.1^{0} \mathrm{~N}$ and $74.89^{\circ} \mathrm{E}$ at an altitude of $1587 \mathrm{~m}$ above MSL, in order to work influence of level and source of sulphur for obtaining higher head and seed yield of cabbage. The soil $(0-15 \mathrm{~cm})$ of experimental site was well drained silty clay loam in texture with $\mathrm{pH} 7.00$, high in organic carbon $(0.97 \%)$, medium in available $\mathrm{N}$ (242.6 $\mathrm{kg} / \mathrm{ha})$, available $\mathrm{P}(21.5 \mathrm{~kg} / \mathrm{ha})$, available $\mathrm{K}$ $(165.6 \mathrm{~kg} / \mathrm{ha})$ and available $\mathrm{S}(22.6 \mathrm{~kg} / \mathrm{ha})$. The experiment was laid in a randomized block design with three replications having 10 treatments comprising different combinations of sulphur levels and sulphur sources viz, 40 $\mathrm{kg} \mathrm{S} \mathrm{ha}^{-1}$ through Gypsum $\left(\mathrm{T}_{1}\right), 70 \mathrm{~kg} \mathrm{~S}^{-1}$ through Gypsum $\left(\mathrm{T}_{2}\right), 100 \mathrm{~kg} \mathrm{~S} \mathrm{ha}^{-1}$ through Gypsum( $\left.\mathrm{T}_{3}\right), 40 \mathrm{~kg} \mathrm{~S}^{-1}$ through Elemental sulphur $\left(\mathrm{T}_{4}\right), 70 \mathrm{~kg} \mathrm{~S} \mathrm{ha}^{-1}$ through Elemental sulphur $\left(\mathrm{T}_{5}\right), 100 \mathrm{~kg} \mathrm{~S}^{-1}$ harough Elemental sulphur $\left(\mathrm{T}_{6}\right), 40 \mathrm{~kg} \mathrm{~S}^{-1}$ through Potassium sulphate $\left(\mathrm{T}_{7}\right), 70 \mathrm{~kg} \mathrm{~S}^{-1}$ through Potassium sulphate $\left(\mathrm{T}_{8}\right), \quad 100 \mathrm{~kg} \quad \mathrm{~S} \mathrm{ha}^{-1}$ through Potassium sulphate $\left(\mathrm{T}_{9}\right)$ and control $\left(\mathrm{T}_{10}\right)$. A uniform dose of nitrogen @150 kg N ha ${ }^{-1}$, Phosphorus@60 kg P $\mathrm{O}_{5} \mathrm{ha}^{-1}$, Potassium @ $60 \mathrm{~kg} \mathrm{~K}_{2} \mathrm{O} \mathrm{kg} \mathrm{ha}{ }^{-1}$ and FYM @ $30 \mathrm{t} \mathrm{ha}^{-1}$ was applied to each plot. Sulphur through different sources and levels as per treatment was applied as basal dose. Elemental sulphur was applied 15 days prior to transplanting of seedling. Cabbage (Golden Acre) was transplanted at $60 \times 45 \mathrm{~cm}$ spacing during first fortnight of April and harvested at fully matured stage. Selected and tagged plants were left in the field for seed production during winter. All other cultural practices were followed as per standard recommendations. The economics of different cultural practices, input and returns for cabbage variety Golden Acre under each treatment combination was worked out to find the most effective and economical treatment.

The details of cost of cultivation of head yield and seed yield of cabbage $\mathrm{ha}^{-1}$, treatment wise added cost and treatment wise cost of cultivation are presented in tables 5 and 6, respectively. The data were analyzed as per the standard procedure for Analysis of Variance (ANOVA) as described by Gomez and Gomez, (1984). The difference in the treatment mean was tested by using critical difference (CD) at 5\% level of probability. 


\section{Results and Discussion}

\section{Head yield (q ha $\left.{ }^{-1}\right)$}

Results showed significant influence of sources and levels of sulphur on head yield (q $\mathrm{ha}^{-1}$ ). Among different sulphur sources, potassium sulphate (Table 1) recorded maximum head yield plot $^{-1}(30.80)$, head yield ha $^{-1}$ (408.40 q ha $\left.{ }^{-1}\right)$, seed yield plant ${ }^{-1}$ (12.90) and seed yield hectare ${ }^{-1}(4.80 \mathrm{q})$ followed by Gypsum and the lowest head yield plant $^{-1}$ $(17.70 \mathrm{~kg})$, head yield ha ${ }^{-1}\left(234.60 \mathrm{q} \mathrm{ha}^{-1}\right)$, seed yield plant ${ }^{-1}(6.00 \mathrm{~g})$ and seed yield $\operatorname{hectare}^{-1}(2.25 \mathrm{q})$. The superiority of potassium cabbage could be attributed to highly soluble nature and readily available sulphur (sulphate) in potassium sulphate as compared to Gypsum and Elemental sulphur (Tandon,1989), (Tandon and Messick, 2002). Similar observations have been reported by Samui and Bandopadhyay (1997) in cauliflower.

Among sulphur levels, $70 \mathrm{~kg} \mathrm{~S} \mathrm{ha}{ }^{-1}$ recorded maximum head yield plot $^{-1}(28.00 \mathrm{~kg})$, head yield $\mathrm{ha}^{-1}\left(371.90 \mathrm{q} \mathrm{ha}^{-1}\right)$, seed yield plant
$(11.90 \mathrm{~g})$ and seed yield hectare ${ }^{-1}(4.4 \mathrm{q})$ but exhibited statistically at par results with $70 \mathrm{~kg}$ $\mathrm{S} \mathrm{ha}^{-1}$ with head yield plant ${ }^{-1}(27.90 \mathrm{~kg})$, head yield ha ${ }^{-1}\left(370.20 \mathrm{q} \mathrm{ha}^{-1}\right)$, seed yield plant ${ }^{-1}$ $(11.40 \mathrm{~g})$ and seed yield hectare ${ }^{-1}$ (4.2 q). The increase in head yield and seed yield might be due to the important role of sulphur in lowering the $\mathrm{pH}$ of soil resulting in increased availability of many nutrients (Hossan and Olsen, 1966). Sulphur application increases the yield, since it is a constituent of amino acid and protein production (Ahmed 1998). Increase in crop yield by the application of sulphur was reported by Tandon (2002).

Sulphur helps in energy transformation and activation of enzymes in carbohydrate metabolism and greater partitioning of photosynthates in yield contributing attributes. The increase in yield attributes was probably due to source and sink relationship which ultimately increased head and seed yield. Increase in seed yield by application of sulphur are in confirmation with the results obtained by Khanpara et al., (1993), Jat and Kangarot (2000), Narwal et al., (1991), Hunashikatti et al., (2000).

Table.1 Yield performance of cabbage as influenced by different sources and levels of sulphur

\begin{tabular}{|c|c|c|c|c|}
\hline Treatment & $\begin{array}{l}\text { Head yield } \\
\text { plant }^{-1}\end{array}$ & $\begin{array}{c}\text { Head } \\
\text { yield ha' }\end{array}$ & $\begin{array}{c}\text { Seed } \\
\text { yield plant }\end{array}$ & $\begin{array}{c}\text { Seed yield } \\
\text { ha }^{-1}\end{array}$ \\
\hline \multicolumn{5}{|l|}{ Sulphur sources } \\
\hline Gypsum & 25.50 & 338.10 & 11.20 & 4.10 \\
\hline Elemental sulphur & 23.30 & 310.00 & 9.00 & 3.30 \\
\hline Potassium sulphate & 30.80 & 408.40 & 12.90 & 4.80 \\
\hline \multicolumn{5}{|l|}{ Graded levels of sulphur $\mathrm{ha}^{-1}$} \\
\hline $40 \mathrm{~kg}$ & 23.70 & 314.60 & 9.80 & 3.65 \\
\hline 70 kg & 27.90 & 370.20 & 11.40 & 4.2 \\
\hline $100 \mathrm{~kg}$ & 28.00 & 371.90 & 11.90 & 4.4 \\
\hline Control versus rest control mean & 17.70 & 234.60 & 6.00 & 2.25 \\
\hline Sources CD $(p \leq 0.05)$ & 0.25 & 3.20 & 0.14 & 0.05 \\
\hline Levels & 0.25 & 3.20 & 0.14 & 0.05 \\
\hline Control versus rest & 0.10 & 1.40 & 0.06 & 0.02 \\
\hline
\end{tabular}


Table.2 Interaction effect of seed yield plant ${ }^{-1}$ as influenced by different sources and Levels of sulphur

\begin{tabular}{|c|c|c|c|}
\hline \multirow[t]{2}{*}{ Treatment } & \multicolumn{3}{|c|}{ Sulphur Levels (kg ha $\left.{ }^{-1}\right)$} \\
\hline & \multicolumn{3}{|c|}{ Seed yield plant $^{-1}\left(\right.$ g plant- $\left.^{1}\right)$} \\
\hline Sulphur sources & 40 & 70 & 100 \\
\hline Gypsum & 9.80 & 11.70 & 12.10 \\
\hline E. sulphur & 7.60 & 9.42 & 10.00 \\
\hline P. sulphate & 12.20 & 13.20 & 13.40 \\
\hline$C D(p \leq 0.05)$ & & 0.08 & \\
\hline
\end{tabular}

Table.3 Cost of cultivation of cabbage head production (Hectare basis)

\begin{tabular}{|c|c|c|}
\hline \multicolumn{2}{|c|}{ Cost involved on variable and fixed factors } & \multirow{2}{*}{$\begin{array}{l}\text { ₹hat }^{-1} \\
1500.00\end{array}$} \\
\hline A. & $\begin{array}{l}\text { Nursery raising/preparation/sowing, management (10 Labourers at } \\
₹ 150.0 \text { labour }^{-1}\end{array}$ & \\
\hline \multicolumn{2}{|r|}{ Total A } & 1550 \\
\hline \multirow[t]{4}{*}{ B. } & Preparatory tillage (Three ploughings at $₹ 3000.00 \mathrm{ha}^{-1}$ ) & 9000.00 \\
\hline & Clod breaking/leveling (20 labourers at $₹ 150.0$ labour $^{-1}$ ) & 3000.00 \\
\hline & Preparation of beds/channels (35 labourers at $₹ 150.00$ labour $^{-1}$ ) & 5250.00 \\
\hline & Planting of seedlings (35 labourers at $₹ 150.0$ labour $^{-1}$ ) & 5250.00 \\
\hline \multicolumn{2}{|c|}{ Total B } & 22500.00 \\
\hline C. & Irrigation (20 labourers at $₹ 150.0$ labour $^{-1}$ ) & 3000.00 \\
\hline D. & $\begin{array}{l}\text { Cultural operations (five hand weedings/hoeings } 55 \text { labourers at } ₹ \\
150.0 \text { labour }^{-1} \text { ) }\end{array}$ & 8250.00 \\
\hline E. & After care operations (15 labourers at $₹ 150.00$ labour $^{-1}$ ) & 2250.00 \\
\hline F. & $\begin{array}{l}\text { Harvesting, and related operations (15 labourers at ₹ } 150.00 \\
\text { labour }^{-1} \text { ) }\end{array}$ & 2250.00 \\
\hline \multicolumn{2}{|c|}{ Total $(\mathrm{C}+\mathrm{D}+\mathrm{E}+\mathrm{F})$} & 15750.00 \\
\hline \multicolumn{2}{|c|}{ Total $(\mathrm{A}+\mathrm{B}+\mathrm{C}+\mathrm{D}+\mathrm{E}+\mathrm{F})$} & 39750.00 \\
\hline & Incidental charges at $5 \%$ of the working capital & 1987.5 \\
\hline & Total labour component involved in total cost of cultivation & 41737.5 \\
\hline G. & Cost of seed at $1000 \mathrm{~kg}^{-1}$ for $500 \mathrm{~g}$ seed ha $^{-1}$ & 500.00 \\
\hline \multicolumn{2}{|c|}{ Total G } & 500.00 \\
\hline \multicolumn{2}{|c|}{ Variable cost (labour + cost of seed) } & 42237.5 \\
\hline \multicolumn{2}{|c|}{ Land rent at $₹ 900 \mathrm{kanal}^{-1}$} & 18000.00 \\
\hline \multicolumn{2}{|c|}{ Land tax } & 80.0 \\
\hline \multicolumn{2}{|c|}{ Depreciation of implements } & 800.0 \\
\hline \multicolumn{2}{|c|}{ Total } & 18880.00 \\
\hline \multicolumn{2}{|c|}{ Interest at $6.5 \%$ on fixed factor } & 1227.2 \\
\hline \multicolumn{2}{|c|}{ Total fixed cost $(18880+1227.2)$} & 20107.2 \\
\hline
\end{tabular}


Table. 4 Cost of cultivation of seed production in cabbage (Hectare basis)

\begin{tabular}{|c|c|c|}
\hline \multicolumn{2}{|c|}{ Cost involved on variable and fixed factors } & \multirow{2}{*}{$\begin{array}{l}\text { F } \text { ha }^{-1} \\
1500.00\end{array}$} \\
\hline A. & Nursery raising/preparation/sowing, management (10 Labourers at $₹ 150.0$ labour $^{-1}$ & \\
\hline \multicolumn{2}{|c|}{ Total A } & 1500 \\
\hline \multirow[t]{4}{*}{ B. } & Preparatory tillage (Three ploughings at $₹ 3000.00 \mathrm{ha}^{-1}$ ) & 9000.00 \\
\hline & Clod breaking/leveling (20 labourers at $₹ 150.0$ labour $^{-1}$ ) & 3000.00 \\
\hline & Preparation of beds/channels ( 35 labourers at $₹ 150.0$ labour $^{-1}$ ) & 5250.00 \\
\hline & Planting of seedlings (35 labourers at $\bar{₹} 150.0$ labour $^{-1}$ ) & 5250.00 \\
\hline \multicolumn{2}{|r|}{ ( } & 22500.00 \\
\hline C. & Irrigation and drainage (45 labourers at $₹ 150.00$ labour $^{-1}$ ) & 12750.00 \\
\hline D. & Cultural operations (fifteen hand weedings/hoeings 85 labourers at $₹ 150.00$ labour $^{-1}$ ) & 5250.00 \\
\hline E. & After care operations (15 labourers at $₹ 150.0$ labour $^{-1}$ ) & 2250.00 \\
\hline F. & $\begin{array}{l}\text { Harvesting, drying, curing, threshing, winnowing, cleaning \& packaging of seed and } \\
\text { related operations ( } 35 \text { labourers at } ₹ 150.0 \text { labour }^{-1} \text { ) }\end{array}$ & 5250.00 \\
\hline \multicolumn{2}{|c|}{ Total $(C+D+E+F)$} & 27000.00 \\
\hline \multicolumn{2}{|c|}{ Total $(\mathrm{A}+\mathrm{B}+\mathrm{C}+\mathrm{D}+\mathrm{E}+\mathrm{F})$} & 51000.00 \\
\hline & Incidental charges at $5 \%$ of the working capital & 2550.00 \\
\hline & Total labour component involved in total cost of cultivation & 53550.00 \\
\hline G. & Cost of seed at $1000 \mathrm{~kg}^{-1}$ for $500 \mathrm{~g}$ seed ha ${ }^{-1}$ & 500.00 \\
\hline \multicolumn{2}{|c|}{ Total G } & $\mathbf{5 0 0 . 0 0}$ \\
\hline \multicolumn{2}{|c|}{ Variable cost (labour + cost of seed) } & 54050 \\
\hline \multicolumn{2}{|c|}{ Land rent at $₹ 900 \mathrm{kanal}^{-1}$} & 18000.00 \\
\hline \multicolumn{2}{|c|}{ Land tax } & 80.00 \\
\hline \multicolumn{2}{|c|}{ Depreciation of implements } & 800.00 \\
\hline \multicolumn{2}{|c|}{ Total } & 18880.00 \\
\hline \multicolumn{2}{|c|}{ Interest at $6.5 \%$ on fixed factor } & 1227.2 \\
\hline \multicolumn{2}{|c|}{ Total fixed cost $(18880.0+1227.2)$} & 20107.2 \\
\hline
\end{tabular}

Table.5 Treatment wise comparative economics of cost of cultivation of cabbage (Hectare basis)

\begin{tabular}{|c|c|c|c|c|c|c|c|c|c|}
\hline Treatment & $\begin{array}{l}\text { Fixed } \\
\text { cost } \\
\left(₹ h^{-1}\right)\end{array}$ & $\begin{array}{l}\text { Variable } \\
\text { cost } \\
\left(₹ \text { ha }^{-1}\right)\end{array}$ & $\begin{array}{l}\text { Total } \\
\text { added } \\
\text { cost } \\
\left(₹ \text { ha }^{-1}\right)\end{array}$ & $\begin{array}{l}\text { Total } \\
\text { variable cost } \\
\left(₹ \text { ha }^{-1}\right)\end{array}$ & $\begin{array}{l}\text { Total cost } \\
\text { of } \\
\text { cultivation } \\
\left(₹ \mathrm{ha}^{-1}\right)\end{array}$ & $\begin{array}{l}\text { Pooled } \\
\text { Head } \\
\text { yield } \\
\left(\mathrm{q} \mathrm{ha} \mathbf{~}^{-1}\right)\end{array}$ & $\begin{array}{l}\text { Gross } \\
\text { returns } \\
\left(₹ \text { ha }^{-1} @\right. \\
\left.₹ 1500 \mathrm{q}^{-1}\right)\end{array}$ & $\begin{array}{l}\text { Net } \\
\text { returns } \\
\left(₹ h^{-1}\right)\end{array}$ & $\begin{array}{l}\text { Returns } \\
\text { per } \\
\text { rupee }\end{array}$ \\
\hline $\begin{array}{l}40 \mathrm{~kg} \mathrm{~S} \text { through } \\
\text { Gypsum }\end{array}$ & 20107.20 & 42237.50 & 72232.40 & 114469.90 & 134577.10 & 301.70 & 452550 & 317972.90 & 3.30 \\
\hline $\begin{array}{l}70 \mathrm{~kg} \mathrm{~S} \text { through } \\
\text { Gypsum }\end{array}$ & 20107.20 & 42237.50 & 75232.40 & 117469.90 & 137577.10 & 355.80 & 533700 & 396122.90 & 4.10 \\
\hline $\begin{array}{l}100 \mathrm{~kg} \mathrm{~S} \text { through } \\
\text { Gypsum }\end{array}$ & 20107.20 & 42237.50 & 78225.20 & 120462.70 & 140569.90 & 357.30 & 535950 & 395380.10 & 3.80 \\
\hline $\begin{array}{l}40 \mathrm{~kg} \mathrm{~S} \text { through } \\
\text { Elemental sulphur }\end{array}$ & 20107.20 & 42237.50 & 108232.80 & 150470.30 & 170577.50 & 273.70 & 410550 & 239972.50 & 2.40 \\
\hline $\begin{array}{l}70 \mathrm{~kg} \mathrm{~S} \text { through } \\
\text { Elemental sulphur }\end{array}$ & 20107.20 & 42237.50 & 138232.80 & 180470.30 & 200577.50 & 327.40 & 491100 & 290522.50 & 2.40 \\
\hline $\begin{array}{l}100 \mathrm{~kg} \mathrm{~S} \text { through } \\
\text { Elemental sulphur }\end{array}$ & 20107.20 & 42237.50 & 168232.80 & 210470.30 & 230577.50 & 329.10 & 493650 & 263072.50 & 2.10 \\
\hline $\begin{array}{l}40 \mathrm{~kg} \mathrm{~S} \text { through } \\
\text { Potassium Sulphate }\end{array}$ & 20107.20 & 42237.50 & 82396.00 & 124633.50 & 144740.70 & 368.40 & 552600 & 407859.30 & 3.80 \\
\hline $\begin{array}{l}70 \mathrm{~kg} \mathrm{~S} \text { through } \\
\text { Potassium Sulphate }\end{array}$ & 20107.20 & 42237.50 & 93829.50 & 136067.00 & 156174.20 & 427.40 & 641100 & 485925.80 & 4.10 \\
\hline $\begin{array}{l}100 \mathrm{~kg} \mathrm{~S} \text { through } \\
\text { Potassium Sulphate }\end{array}$ & 20107.20 & 42237.50 & 105341.00 & 147578.50 & 167685.70 & 429.40 & 644100 & 476414.30 & 3.80 \\
\hline Control & 20107.20 & 42237.50 & 68232.80 & 110470.30 & 130577.50 & 234.60 & 351900 & 221322.50 & 2.70 \\
\hline
\end{tabular}


Table.6 Treatment wise comparative economics of cost of cultivation of seed production in Cabbage (Hectare basis)

\begin{tabular}{|c|c|c|c|c|c|c|c|c|c|}
\hline Treatment & $\begin{array}{l}\text { Fixed } \\
\text { cost } \\
\left(₹ \text { ha }^{-1}\right)\end{array}$ & $\begin{array}{l}\text { Variable } \\
\text { cost } \\
\left(₹ \text { ha }^{-1}\right)\end{array}$ & $\begin{array}{l}\text { Total } \\
\text { added } \\
\text { cost } \\
\left(₹ \text { ha }^{-1}\right) \\
\end{array}$ & $\begin{array}{l}\text { Total } \\
\text { variable } \\
\text { cost } \\
\left(₹ \text { ha }^{-1}\right) \\
\end{array}$ & $\begin{array}{l}\text { Total cost } \\
\text { of } \\
\text { cultivation } \\
\left(₹ \mathrm{ha}^{-1}\right)\end{array}$ & $\begin{array}{l}\text { Pooled } \\
\text { seed } \\
\text { yield } \\
\left(\mathbf{q ~ h a} \mathbf{~ h}^{-1}\right)\end{array}$ & $\begin{array}{l}\text { Gross } \\
\text { returns } \\
\left(₹ \text { ha }^{-1} @\right. \\
\left.₹ 100000 \text { q }^{-1}\right)\end{array}$ & $\begin{array}{l}\text { Net } \\
\text { returns } \\
\left(₹ \text { ha }^{-1}\right)\end{array}$ & $\begin{array}{l}\text { Returns } \\
\text { per } \\
\text { rupee }\end{array}$ \\
\hline $\begin{array}{l}40 \mathrm{~kg} \mathrm{~S} \text { through } \\
\text { Gypsum }\end{array}$ & 20107.20 & 54050.00 & 72232.40 & 126282.40 & 146389.60 & 3.62 & 362000 & 135347.90 & 2.40 \\
\hline $\begin{array}{l}70 \mathrm{~kg} \mathrm{~S} \text { through } \\
\text { Gypsum }\end{array}$ & 20107.20 & 54050.00 & 75232.40 & 129282.40 & 149389.60 & 4.32 & 432000 & 184947.90 & 2.80 \\
\hline $\begin{array}{l}100 \mathrm{~kg} \mathrm{~S} \text { through } \\
\text { Gypsum }\end{array}$ & 20107.20 & 54050.00 & 78225.20 & 132275.20 & 152382.40 & 4.53 & 453000 & 197605.10 & 2.90 \\
\hline $\begin{array}{l}40 \mathrm{~kg} \mathrm{~S} \text { through } \\
\text { Elemental sulphur }\end{array}$ & 20107.20 & 54050.00 & 108232.80 & 162282.80 & 182390.00 & 2.81 & 281000 & 38597.50 & 1.50 \\
\hline $\begin{array}{l}70 \mathrm{~kg} \mathrm{~S} \text { through } \\
\text { Elemental sulphur }\end{array}$ & 20107.20 & 54050.00 & 138232.80 & 192282.80 & 212390.00 & 3.48 & 348000 & 58947.50 & 1.60 \\
\hline $\begin{array}{l}100 \mathrm{~kg} \mathrm{~S} \text { through } \\
\text { Elemental sulphur }\end{array}$ & 20107.20 & 54050.00 & 168232.80 & 222282.80 & 242390.00 & 3.7 & 370000 & 45347.50 & 1.50 \\
\hline $\begin{array}{l}40 \mathrm{~kg} \mathrm{~S} \text { through } \\
\text { Potassium Sulphate }\end{array}$ & 20107.20 & 54050.00 & 82396.00 & 136446.00 & 156553.20 & 4.52 & 452000 & 192684.30 & 2.80 \\
\hline $\begin{array}{l}70 \mathrm{~kg} \mathrm{~S} \text { through } \\
\text { Potassium Sulphate }\end{array}$ & 20107.20 & 54050.00 & 93829.50 & 147879.50 & 167987.20 & 4.89 & 489000 & 209000.30 & 2.90 \\
\hline $\begin{array}{l}100 \mathrm{~kg} \mathrm{~S} \text { through } \\
\text { Potassium Sulphate }\end{array}$ & 20107.20 & 54050.00 & 105341.00 & 159391.00 & 179498.20 & 4.98 & 498000 & 204239.30 & 2.70 \\
\hline Control & 20107.20 & 54050.00 & 68232.80 & 122282.80 & 142390.00 & 2.24 & 224000 & 35947.50 & 1.50 \\
\hline
\end{tabular}

The interaction effect between sources and levels of sulphur on head yield ha ${ }^{-1}$ (q) in pooled data was found to be non-significant. The interaction effect between sources and levels of sulphur seed yield plant ${ }^{-1}$ was found significant (Table 2). The seed yield plant $^{-1}$ varied significantly among different sulphur sources when fertilizer sulphur was applied as Gypsum, Elemental sulphur and Potassium Sulphate. Similarly at 40, 70, and 100 $\mathrm{kg} \mathrm{S} \mathrm{ha}{ }^{-1}$, seed yield plant ${ }^{-1}$ significantly higher seed yield plant ${ }^{-1}$ in pooled data of $13.20 \mathrm{~g}$ was recorded with treatment combination $100 \mathrm{~kg} \mathrm{~S}^{-1}$ potassium sulphate which was statistically superior to all other treatment combination.

\section{Economics}

\section{Cabbage head production}

The data presented in table 3 revealed position of input and output in terms of economics of production. The treatment wise cost of cultivation and returns revealed that maximum net returns of ₹ $485925.8 \mathrm{ha}^{-1}$ were observed with the application of $70 \mathrm{~kg} \mathrm{~S} \mathrm{ha}^{-1}$ as Potassium Sulphate followed by ₹476414.3 ha $^{-1}$ with the application of $100 \mathrm{~kg} \mathrm{~S} \mathrm{ha}^{-1}$ as Potassium Sulphate with benefit cost ratio of 4.1 and 3.8, respectively. The lowest net returns of $₹ 221322.5$ were registered with control with benefit cost ratio of 2.7 .

\section{Seed production}

The data presented in table 5 revealed position of input and output in terms of economics of production. The treatment wise cost of cultivation and returns revealed that maximum net returns of ₹ $321013.0 \mathrm{ha}^{-1}$ were observed with the application of $70 \mathrm{~kg} \mathrm{~S}^{-1}$ as Potassium Sulphate followed by $₹ 300617.6 \mathrm{ha}^{-1}$ with the application of $100 \mathrm{~kg} \mathrm{~S} \mathrm{ha}^{-1}$ as Potassium Sulphate with benefit cost ratio of 3.0 and 2.9 respectively. The lowest net returns of $₹ 81610.0$ were registered with control with benefit cost ratio of 1.5. Similar results have been reported by Jamre et al. (2010) in cabbage and Chippa (2005) in cauliflower.

From the above study, it is concluded that the sulphur application improves yield of cabbage irrespective of sources and increasing levels of 
sulphur showed significant results. In terms of cost of cultivation potassium sulphate as a source of sulphur with a level of $70 \mathrm{~kg} \mathrm{ha}^{-1}$ proved to be best combination.

\section{References}

Ahmad, A., Abraham, G., Gandotra, N., Abrol, Y.P. and Abdin, M.Z. 1998. Interactive effect of nitrogen and sulphur on growth and yield of rapeseed-mustard (Brassica juncea [L.] Czern 527 and Coss and Brassica campestris L.). Journal of Agronomy Crop Sciences, 181: 193-199.

Anonymous, 2011. Technical Note March 2012, Horticulture Unit.

Anonymous, 2012a. Report from Govt. of J\&K Directorate of Agriculture, Kashmir.

Chhipa, B.G., 2005. Effect of different levels of sulphur and zinc on growth and yield of cauliflower (Brassica oleracea var. botrytis L.). M.Sc. (Ag.) Thesis, S.K.N. College of Agriculture, Jobner, RAU, Bikaner Cripps.

Gomez, K.A., and Gomez, A.A. 1984. Statistical Procedures for Agricultural Research. $2^{\text {nd }}$ edition. John Wiley and Sons, Inc. New York.

Hara, T., and Sonoda, Y. 1981. The role of macronutrients in cabbage head formation. Soil Science and Plant Nutrition, 27(1): 45-54.

Hossan, N., and Olsen, R.A. 1966. Influence of applied sulphur on availability of soil nutrients of corn (Zea mays L.) nutrition. Proceedings of Soil Science and Society of America, 30(2): 284-286.

Hunashikatti, M.H., Channal, H.T., Sarangamath, P.A., Manjunathaiah, H.M. and Hebsur, N.S. 2000. Effect of sulphur and molybdenum on the dry matter yield and uptake of $\mathrm{S}$ and Mo by cabbage. Karnataka Journal of Agricultural Science, 13(4): 840-
845.

Jamal, A., Moon, Y.S., and Abdin, M.Z. 2010. Sulphur-A general overview and interaction with nitrogen. Australian. Journal of Crop Sciences, 4: 523-529

Jamre, B.R., Nagaich, K.N. and Verma, Hemlata. 2010. Effect of different levels of sulphur and Zinc on growth and yield of cauliflower (Brassica oleracea var. botrytis L.). Asian Journal of Horticulture, 5 (2): 323-325.

Jat, B.L, and Khangarot, S.S. 2000. Responses of mustard (Brassica Juncea L.) varieties to different levels of sulphur in loamy sand soil. Agriculture Science Digest, 23 (2):149-151, 2003.

Khanpara, V.D., Porwal, B.L., Sahu, M.P and Patel, J.C. 1993. Effect of nitrogen and sulphur on growth and yield of mustard (Brassica juncea). Indian Journal of Agronomy, 38(2): 266-269.

Narwal, R.P., Gupta, A.P., Ksrwasara, S.P.S and Antil, R.S. 1991. Effect of carriers of sulphur on yield and uptake of sulphur by mustard. Journal of Indian Society of Soil Science, 39(2):34-327.

Samui, R.C., and Bandopadhyay, P. 1997. Effect of sources level and method of application of sulphur on Indian mustard (Brassica juncea). Indian Journal of Agricultural Sciences, 67(8):305-307.

Tandon, H.L.S., 1989. Sulphur fertilizers for Indian Agriculture-A Guide book Fertilizer Development and Consultation Organization. New Delhi.

Tandon, H.L.S., 2002. Sulphur fertilizers for Indian Agriculture-A Guide book Fertilizer Development and Consultation Organization. New Delhi.

Tandon, H.L.S., and Messick. 2002. Practical Sulphur Guide. Connecticut Avenue, N.W., Suite 612 Washington D.C U.S.A. pp. 2-19.

\section{How to cite this article:}

Bhat, R., Shahid B. Dar and Zahida, R. 2017. Yield Performance and Economic Studies of Cabbage (Brassica oleracea var. capitata) as Influenced by Different Sources and Levels of Sulphur. Int.J.Curr.Microbiol.App.Sci. 6(10): 322-328. doi: https://doi.org/10.20546/ijcmas.2017.610.039 